\title{
Pengaruh Kepemimpinan dan Lingkungan Kerja terhadap Motivasi dan Kinerja Perangkat Desa di Kecamatan Wedi, Kabupaten Klaten
}

\author{
Muhammad Aga Sekamdo \\ Sekolah Tinggi Ilmu Administrasi Madani \\ Erry Setyo Prabowo \\ Sekolah Tinggi Ilmu Administrasi Madani \\ Eko Wiratno* \\ Sekolah Tinggi Ilmu Administrasi Madani \\ *ekowiratno@stiamadani.ac.id
}

\begin{abstract}
This study aims to determine the role of leadership and work environment influence on the motivation and performance of village officials in Wedi, District, Klaten Regency, Central Java Province. The data analysis technique used is path analysis, tested by t test, F test, and $R 2$ test, correlation, direct and indirect effects and total effect. The questionnaire data collection technique, the sample used was the village officials in Wedi District, Klaten Regency, which amounted to 50 respondents. The results showed that leadership had a positive and significant effect on work motivation of village officials, the work environment had a positive and significant effect on work motivation of village officials, leadership had a positive and not significant effect on the performance of village officials, the work environment had a positive and significant effect on the performance of village officials. Based on el value and e2 value, the total $R 2$ value is $79.84 \%$. This means that the performance of village officials is explained by the variables of leadership, work environment, motivation as an intervening or mediating variable of 79.84 and the remaining $20.16 \%$ is explained by other variables outside this study, for example organizational behavior, organizational culture, communication, education and training, and others.
\end{abstract}

Keyword leadership, work environment, motivation, and performance

\section{PENDAHULUAN}

Pemerintah desa adalah struktur pemerintahan yang paling kecil di negara kesatuan Republik Indonesia, yang berfungsi dalam pelaksanaan program pemerintah yang ada di atasnya. Faktor yang mempengaruhi kinerja adalah kepemimpinan. Peranan kepala desa sebagai pemimpin organisasi pemerintahan di tingkat desa sangat penting dalam keberhasilan pelaksanaan tugas perangkat desa. Kepemimpinan kepala desa dalam memberi contoh yang baik sebagai pemimpin akan menarik perangkat desa untuk dapat bekerjasama dengan baik, untuk tercipta kinerja yang tinggi dalam mencapai tujuan organisasi.

Lingkungan kerja adalah faktor-faktor di luar manusia baik fisik maupun non fisik dalam menunjang pekerjaan. Lingkungan kerja yang dalam hal ini kantor desa yang ada di Kecamatan Wedi, Kabupaten Klaten untuk mendukung proses pelayanan kepada masyarakat.

Motivasi diartikan sebagai dorongan jiwa atau moral untuk berbuat sesuatu. Apabila motivasi kerja perangkat desa dapat digerakkan maka akan menjadi pendorong baginya untuk 
melaksanakan aktivitas tugas secara optimal karena motivasi seseorang dapat mempengaruhi perilakunya.

\section{LANDASAN TEORI.}

\section{Kinerja}

Kinerja merupakan suatu istilah yang sering digunakan dalam perencanaan pengembangan industri pada khususnya, dan perencanaan pengembangan ekonomi nasional pada umumnya. Produktivitas dalam dunia birokrasi merupakan hal yang sangat penting karena dengan adanya kinerja diharapkan pekerjaan akan terlaksana secara efisien dan efektif. Produktivitas kerja pada hakikatnya sebuah motif ekonomi untuk memperoleh hasil sebanyak mungkin dengan biaya tertentu. Kinerja kerja sebagai sebuah aksentuasi motif ekonomi dalam hal pelaksanaan kegiatan organisasi yang banyak ditentukan oleh faktor manusia

Menurut Bernardian dan Russell dalam Sedarmayanti (2011) kinerja (performance) is defined as the record of outcomes produced on a specific job function or activity during a specific time period (kinerja didefinisikan sebagai catatan mengenai outcome yang dihasilkan dari suatu aktivitas tertentu selama kurun waktu tertentu pula).

\section{Lingkungan Kerja}

Lingkungan kerja merupakan lingkungan di sekitar pekerjaan yang mempengaruhi kinerja kerja seorang individual dalam melakukan pekerjaannya. Setiap organisasi dalam hal ini pemimpin harus dapat menciptakan suasana yang mendukung pelaksanaan tugas masing-masing individu dalam organisasi. Harmonisasi tujuan organisasi dengan individu yang terlibat dalam organsiasi tersebut penting karena dapat menyamakan persepsi antara tujuan organsiasi dengan tujuan individu. Persamaan visi dan misi antara organisasi dengan para perangkat desa akan mempercepat pencapaian target ataupun tujuan yang telah ditetapkan oleh perusahaan.

\section{Kepemimpinan}

Kepemimpinan dapat didefinisikan sebagai suatu kepribadian yang mendatangkan keinginan suatu kelompok untuk menirunya atau mengikutinya, atau memancarkan pengaruh tertentu sebagai suatu kewibawaan yang membuat kelompok orang untuk melakukan perbuatan yang dikehendaki (Karyadi, 2012).

Menurut Timpe (2011) kepemimpinan adalah seni mempengaruhi dan mengarahkan orang dengan cara kepatuhan, kepercayaan, hormat dan kerja sama yang bersemangat dalam mencapai tujuan bersama. Suprihanto (2013) memberikan definisi kepemimpinan sebagai upaya mempengaruhi pengikut melalui proses komunikasi untuk mencapai tujuan tertentu. Kepemimpinan sebagai proses mempengaruhi orang-orang lain untuk mengambil tindakan,. Pemimpin mempengaruhi para pengikutnya lewat berbagai cara, misalnya dengan menciptakan keteladanan, penetapan sasaran, member imbalan dan hukuman dan mengkomunikasikan sebuah misi.

\section{Motivasi}

Menurut Sardiman A.M (2011), istilah motivasi berasal dari kata motif yang dapat diartikan sebagai kekuatan yang terdapat dalam diri individu, yang menyebabkan individu tersebut bertindak atau berbuat. Motif tidak dapat di amati secara langsung, tetapi dapat diinterprestasikan dalam tingkah lakunya, berupa rangsangan, dorongan, atau pembangkit tenaga munculnya suatu tingkah laku tertentu.

Menurut Hasibuan (2011) definisi motivasi adalah kemauan untuk berjuang atau berusaha ke tingkat yang lebih tinggi menuju tercapainya tujuan organisasi dengan syarat tidak mengabaikan kemampuannya untuk memperoleh kepuasan dalam pemenuhan kebutuhankebutuhan pribadi. Pendapat lain menurut Siagian (2012) motivasi adalah segala sesuatu yang menjadi pendorong tingkah laku yang menuntut atau mendorong orang untuk memenuhi suatu kebutuhan.Motivasi merupakan masalah yang komplek pada organisasi atau instansi, karena 
motivasi setiap pegawai atau sumber daya manusia berbeda satu sama lain. Manusia merupakan makhluk yang unik baik secara fisik maupun mental. Untuk itu seorang pimpinan harus mengetahui motivasi pegawainya, sebab faktor ini penting untuk mengoptimalkan kinerja sumber daya manusia, yang akhirnya untuk mencapai tujuan instansi.

\section{METODE PENELITIAN}

Penelitian dilaksanakan di Kantor Desa se- Kecamatan Wedi, Kabupaten Klaten, Jawa Tengah. Populasi dalam penelitian ini adalah Perangkat Desa (baik Kepala Desa, Sekretaris Desa, Kepala Dusun, Kepala Urusan Pemerintahan, Kepala Urusan Umum atau Staf yang berjumlah 50 orang). Sampel adalah bagian dari jumlah dan karakteristik yang dimiliki oleh populasi tersebut (Sugiyono, 2012).

\section{HASIL PENELITIAN}

\section{a. Gambaran Umum Objek Penelitian}

Penelitian ini untuk mengkaji pengaruh kepemimpinan dan lingkungan kerja dalam meningkatkan kinerja para perangkat desa dikecamatan Wedi, Kabupaten Klaten melalui motivasi sebagai variabel mediasi. Obyek penelitian ini adalah perangakat desa di Kecamatan Wedi, Kabupaten Klaten. Sampel dalam penelitian ini berjumlah 50 perangkat desa. Teknik sampling yang digunakan untuk penentuan sampel adalah random sampling yaitu semua responden mempunyai kesempatan yang sama atau acak. Sebagai deskripsi responden dimana merupakan 50 perangkat desa dapat diperlihatkan beberapa karakteristik umum dari responden sebagai berikut:

Tabel 1. Responden Berdasarkan Jenis Kelamin

\begin{tabular}{|c|l|c|c|}
\hline No & \multicolumn{1}{|c|}{ Jenis Kelamin } & $\begin{array}{c}\text { Frekuensi } \\
\text { (orang) }\end{array}$ & $\begin{array}{c}\text { Prosentase } \\
(\boldsymbol{\%})\end{array}$ \\
\hline 1. & Laki-laki & 41 & 82 \\
\hline 2. & Perempuan & 9 & 18 \\
\hline & Jumlah & 50 & 100 \\
\hline
\end{tabular}

Sumber: Data Perangkat Desa 2021

Tabel 2. Responden Berdasarkan Usia

\begin{tabular}{|c|c|c|c|}
\hline $\mathrm{N}$ & Kelompok Usia & $\begin{array}{c}\text { Frekuensi } \\
\text { (orang) }\end{array}$ & $\begin{array}{c}\text { Prosentase } \\
(\%)\end{array}$ \\
\hline 1. & $<30 \mathrm{Th}$ & 9 & 18 \\
\hline 2. & $31-40 \mathrm{Th}$ & 20 & 40 \\
\hline 3. & $41-50 \mathrm{Th}$ & 14 & 28 \\
\hline 4. & $>50$ tahun & 7 & 14 \\
\hline & Jumlah & 50 & 100 \\
\hline
\end{tabular}

Sumber: Kuisioner Perangkat Desa 2021

Tabel 3. Responden Berdasarkan Jenjang Pendidikan

\begin{tabular}{|c|c|c|c|}
\hline No & Pendidikan & $\begin{array}{c}\text { Frekuensi } \\
\text { (orang) }\end{array}$ & $\begin{array}{c}\text { Prosentase } \\
(\%)\end{array}$ \\
\hline 1. & S2 & 1 & 2 \\
\hline 2. & S1 & 11 & 22 \\
\hline 3 & D3 & 5 & 10 \\
\hline 4 & SLTA & 33 & 66 \\
\hline & Jumlah & 50 & 100 \\
\hline
\end{tabular}

Sumber: Kuisioner Perangkat Desa 2021 


\section{b. Hasil dan Analisis}

1) Uji Validitas

Tabel 4.Korelasi item pertanyaan terhadap variabel Kepemimpinan

\begin{tabular}{|c|c|c|c|}
\hline Item Pertanyaan & $\mathrm{r}_{\text {item }}$ & $\mathrm{r}_{\text {tabel }}$ & Keterangan \\
\hline X1.1 & 0,712 & 0,194 & Valid \\
X1.2 & 0,382 & 0,194 & Valid \\
X1.3 & 0,448 & 0,194 & Valid \\
X1.4 & 0,564 & 0,194 & Valid \\
X1.5 & 0,529 & 0,194 & Valid \\
X1.6 & 0,589 & 0,194 & Valid \\
X1.7 & 0,758 & 0,194 & Valid \\
\hline
\end{tabular}

Sumber: Lampiran Hasil Olah Data

Tabel 5. Korelasi item pertanyaan variabel Lingkungan Kerja

\begin{tabular}{|c|c|c|c|}
\hline Item Pertanyaan & $\mathrm{r}_{\text {item }}$ & $\mathrm{r}_{\text {tabel }}$ & Keterangan \\
\hline X2.1 & 0,626 & 0,194 & Valid \\
X2.2 & 0,350 & 0,194 & Valid \\
X2.3 & 0,546 & 0,194 & Valid \\
X2.4 & 0,600 & 0,194 & Valid \\
X2.5 & 0,590 & 0,194 & Valid \\
\hline
\end{tabular}

Sumber: Lampiran Hasil Olah Data

Variabel Lingkungan Kerja terdiri dari 5 item pertanyaan. Pengujian validitas menggunakan teknik one shot methods yaitu dengan membandingkan nilai $\mathrm{r}_{\text {hitung }}$ dengan nilai $\mathrm{r}_{\text {tabel }}=0,194$ dan didapatkan hasil dari 5 item pertanyaan semua valid karena mempunyai nilai $r_{\text {item }}$ lebih besar dari nilai $r_{\text {tabel. }}$.

Tabel 6. Korelasi item pertanyaan terhadap Motivasi

\begin{tabular}{|c|c|c|c|}
\hline Item Pertanyaan & $\mathrm{r}_{\text {item }}$ & $\mathrm{r}_{\text {tabel }}$ & Keterangan \\
\hline X3.1 & 0,479 & 0,194 & Valid \\
X3.2 & 0,716 & 0,194 & Valid \\
X3.3 & 0,765 & 0,194 & Valid \\
X3.4 & 0,796 & 0,194 & Valid \\
X3.5 & 0,773 & 0,194 & Valid \\
X3.6 & 0,796 & 0,194 & Valid \\
X3.7 & 0,773 & 0,194 & Valid \\
\hline
\end{tabular}

Sumber: Data yang diolah, 2021

Tabel 7. Korelasi item pertanyaan terhadap variabel Kinerja

\begin{tabular}{|c|c|c|c|}
\hline Item Pertanyaan & $\mathrm{r}_{\text {item }}$ & $\mathrm{r}_{\text {tabel }}$ & Keterangan \\
\hline Y.1 & 0,652 & 0,194 & Valid \\
Y.2 & 0,393 & 0,194 & Valid \\
Y.3 & 0,367 & 0,194 & Valid \\
Y.4 & 0,559 & 0,194 & Valid \\
\hline
\end{tabular}

Sumber: Lampiran Hasil Olah Data

\section{2) Uji Reliabilitas}


Untuk menguji reliabilitas akan digunakan Cronbach alpha $(\alpha)$ dengan program SPSS (Statistical Product Service Solution). Instrumen dinyatakan valid apabila nilai alpha $(\alpha)>$ 0,6 . Hasil uji reliabilitas dapat dilihat pada tabel IV.4. sebagai berikut:

Tabel 8. Hasil uji reliabilitas

\begin{tabular}{|l|c|c|c|}
\hline \multicolumn{1}{|c|}{ Variabel } & Alpha Cronbach & Kriteria & Keterangan \\
\hline Kepemimpinan & 0,788 & Alpha Cronbach>0,60 maka reliabel & Reliabel \\
Lingkungan Kerja & 0,757 & & Reliabel \\
Motivasi & 0,910 & & Reliabel \\
Kinerja & 0,688 & & Reliabel \\
\hline
\end{tabular}

Sumber: Data yang diolah, 2021

Hasil pengujian reliabilitas menunjukkan bahwa dari hasil pengujian reliabilitas menunjukkan bahwa koefisien (r) alpha hitung seluruh variabel lebih besar dibandingkan dengan kriteria yang dipersyaratkan atau nilai kritis (rule of thumb) sebesar 0,6 sehingga dapat dikatakan bahwa butir-butir pertanyaan seluruh variabel dalam keadaan reliabel.

\section{3) Uji Linieritas}

Uji linieritas yang akan dilakukan adalah dengan uji Lagrange Multiplivariat. Estimasi dengan uji ini bertujuan untuk mendapatkan nilai $\mathrm{C}^{2}$ hitung atau $\left(\mathrm{n} \times \mathrm{R}^{2}\right)$. Hasil uji linieritas sebagai berikut:

Tabel 9. Uji Linieritas

\begin{tabular}{|c|c|c|c|c|}
\hline \multicolumn{5}{|c|}{ Model Summary } \\
\hline Model & $\mathrm{R}$ & R Square & $\begin{array}{l}\text { Adjusted } \\
\text { R Square }\end{array}$ & $\begin{array}{l}\text { Std. Error of } \\
\text { the Estimate }\end{array}$ \\
\hline 1 &, $020^{a}$ & ,000 &,- 031 & ,44590999 \\
\hline
\end{tabular}

a. Predictors: (Constant), Motivasi, Lingkungan Kerja, Kepemimpinan.

Sumber: Data yang diolah 2021

Uji linieritas merupakan langkah untuk mengetahui status linier tidaknya suatu distribusi sebuah data penelitian. Hasil yang diperoleh melalui uji linieritas akan menentukan teknik analisis regresi yang akan digunakan. Jika hasil uji linieritas merupakan data yang linier maka digunakan analisis regresi linier. Sebaliknya jika hasil uji linieritas merupakan data yang tidak linier maka analisis regresi yang akan digunakan non linier.

Dari hasil uji linieritas menunjukkan nilai $\mathrm{R}^{2}$ sebesar 0,000 dengan jumlah sampel 50, besarnya nilai $\mathrm{c}^{2}$ hitung $=50 \times 0,000=0$ sedangkan nilai $\mathrm{c}^{2}$ tabel sebesar 55,75 Nilai $\mathrm{c}^{2}$ hitung < $\mathrm{c}^{2}$ tabel jadi dapat disimpulkan bahwa model yang benar adalah model linier.

\section{4) Analisis Jalur}

Analisis ini digunakan untuk mengetahui pengaruh dari variabel bebas terhadap variabel terikat dengan menggunakan 2 (dua) persamaan. Hasil dari olah data sebagai berikut:

Tabel 10. Hasil Analisis Jalur Persamaan 1

Coefficients $^{\mathbf{a}}$

\begin{tabular}{|l|r|r|r|r|r|}
\hline \multirow{2}{*}{ Model } & \multicolumn{2}{|c|}{ Unstandardized Coefficient } & Standardized Coefficients & t & Sig \\
\cline { 2 - 3 } & \multicolumn{1}{|c|}{ B } & Std. Error & & & \\
\hline 1 Constant & 5,613 & 2,689 & & 2,088 &, 039 \\
Kepemimpinan &, 827 &, 189 &, 687 & 4,370 &, 000 \\
Lingkungan Kerja &, 019 & 0,243 &, 012 &, 077 &, 939 \\
\hline
\end{tabular}

a. Dependent Variabel : Motivasi

Sumber: Lampiran Hasil Olah Data 


\section{a. Hasil Analisis Jalur Persamaan 1}

Ket :

$$
Y_{1}=0,687 X_{1}+0,012 X_{2}+\epsilon
$$

$\mathrm{Y}_{1}=$ Motivasi

$\mathrm{X}_{1}=$ Kepemimpinan

$\mathrm{X}_{2}=$ Lingkungan Kerja

Berikut ini penjelasan dari persamaan 1 analisis regresi jalur:

1) $\beta_{1}=$ sebesar 0,687 menunjukkan bahwa variabel kepemimpinan berpengaruh positif terhadap motivasi.

2) $\beta_{2}=$ sebesar 0,012 menunjukkan bahwa variabel lingkungan kerja berpengaruh positif terhadap motivasi.

\section{b. Hasil Persamaan 2}

Tabel 11. Hasil Analisis Jalur Persamaan 2

Coefficients $^{\mathrm{a}}$

\begin{tabular}{|l|c|c|c|c|c|}
\hline \multirow{2}{*}{ Model } & \multicolumn{2}{|c|}{$\begin{array}{c}\text { Unstandardized } \\
\text { Coefficient }\end{array}$} & $\begin{array}{l}\text { Standardized } \\
\text { Coefficients }\end{array}$ & $\mathrm{t}$ & Sig \\
\cline { 2 - 6 } & \multicolumn{1}{|c|}{$\mathrm{B}$} & Std. Error & Beta & & \\
\hline 1. (Constant) &,- 289 &, 558 & &,- 518 &, 606 \\
Kepemimpinan &, 169 &, 042 &, 275 & 4,025 &, 000 \\
Lingkungan Kerja &, 511 &, 049 &, 645 & 10,345 &, 000 \\
Motivasi &, 046 &, 021 &, 090 & 2,237 &, 028 \\
\hline
\end{tabular}

Sumber: Data yang diolah 2021

Dari tabel di atas dapat dibuat persamaan ke dua sebagai berikut:

$Y_{2}=0,275 X_{1}+0,645 X_{2}+0,090 X_{3}+\epsilon$

Ket :

$\mathrm{Y}_{2}=$ Kinerja Perangkat

$\mathrm{X}_{1}=$ Kepemimpinan

$\mathrm{X}_{2}=$ Lingkungan Kerja

$\mathrm{X}_{3}=$ Motivasi

Penjelasan dari persamaan 2 analisis regresi jalur:

1) $\beta_{1}=0,275$ yang artinya kepemimpinan berpengaruh positif terhadap kinerja perangkat desa, Apabila kepemimpinan ditingkatkan maka kinerja perangkat desa meningkat.

2) $\beta_{2}=0,645$ yang artinya lingkungan kerja berpengaruh positif terhadap kinerja perangkat desa, Apabila lingkungan kerja nyaman maka kinerja otomatis meningkat.

3) $\beta_{3}=0,090$ yang artinya motivasi berpengaruh positif terhadap kinerja perangkat desa.

Apabila motivasi ditingkatkan, maka kinerja karyawan akan meningkat.

\section{a. Uji Hipotesis Parsial (uji t)}

Tabel 12. Hasil Regresi Persamaan 1

\begin{tabular}{|l|c|c|c|c|c|}
\hline \multicolumn{1}{|c|}{ Model } & \multicolumn{6}{|c|}{$\begin{array}{c}\text { Coefficients } \\
\text { Coefficient }\end{array}$} & $\begin{array}{c}\text { Standardized } \\
\text { Coefficients } \\
\text { Beta }\end{array}$ & $\mathrm{t}$ & Sig \\
\cline { 2 - 5 } & $\mathrm{B}$ & Std. Error & & & \\
\hline 1. Constant & 5,613 & 2,689 & & 2,088 &, 039 \\
Kepemimpinan &, 827 &, 189 &, 687 & 4,370 &, 000 \\
Lingkungan Kerja &, 019 &, 243 &, 012 &, 077 &, 939 \\
\hline
\end{tabular}

a. Dependent Variabel : Motivasi.

Sumber: Data yang diolah 2021

Tabel 13, Hasil Regresi Persamaan 2 


\begin{tabular}{|l|c|c|c|c|c|}
\multicolumn{1}{|c|}{ Coefficients $^{\mathbf{a}}$} \\
& \multicolumn{2}{|c|}{$\begin{array}{c}\text { Unstandardized } \\
\text { Coefficient }\end{array}$} & $\begin{array}{l}\text { Standardized } \\
\text { Coefficients }\end{array}$ & & \\
\cline { 2 - 5 } & $\mathrm{B}$ & Std. Error & & $\mathrm{t}$ & Sig \\
\hline 1. Constant &,- 289 &, 558 & &,- 518 &, 606 \\
Kepemimpinan &, 169 &, 042 &, 275 & 4,025 &, 120 \\
Lingkungan Kerja &, 511 &, 049 &, 645 & 10,345 &, 001 \\
Motivasi &, 046 &, 021 &, 090 & 2,237 &, 000 \\
\hline
\end{tabular}

A. Dependent variable : kinerja Sumber: Data yang diolah 2021

Dari tabel IV.8 dan tabel IV.9 dapat disimpulkan sebagai berikut:

a. Kepemimpinan berpengaruh signifikan terhadap motivasi Perangkat Desa di Kecamatan Wedi, Kabupaten Klaten, hal ini dapat dilihat dari signifikansi yaitu $0,000<0,05$.

H1: Kepemimpinan berpengaruh signifikan terhadap motivasi Perangkat Desa di Kecamatan Wedi, Kabupaten Klaten (Hipotesis terbukti).

b. Lingkungan kerja berpengaruh signifikan terhadap motivasi Perangkat Desa di Kecamatan Wedi, Kabupaten Klaten, hal ini dapat dilihat dari nilai signifikansi yaitu 0,000<0,05.

H2: Lingkungan kerja berpengaruh signifikan terhadap motivasi Perangkat Desa di Kecamatan Wedi, Kabupaten Klaten (Hipotesis terbukti).

c. Kepemimpinan berpengaruh signifikan terhadap kinerja perangkat desa di Kecamatan Wedi, Kabupaten Klaten, hal ini dapat dilihat dari nilai signifikansi yaitu 0,000>0,05.

H3: Kepemimpinan berpengaruh signifikan terhadap kinerja perangkat desa di di Kecamatan Wedi, Kabupaten Klaten (Hipotesis terbukti).

d. Lingkungan kerja berpengaruh signifikan terhadap kinerja perangkat desa di Kecamatan Wedi, Kabupaten Klaten, hal ini dapat dilihat dari signifikansi yaitu 0,001 $<0,05$.

H4: Lingkungan kerja berpengaruh signifikan terhadap kinerja Perangkat Desa di Kecamatan Wedi, Kabupaten Klaten (Hipotesis terbukti).

e. Motivasi berpengaruh signifikan terhadap kinerja perangkat desa di di Kecamatan Wedi, Kabupaten Klaten, hal ini dapat dilihat dari nilai signifikansi yaitu $0,000<0,05$

H5: Motivasi berpengaruh signifikan terhadap kinerja perangkat desa di Kecamatan Wedi, Kabupaten Klaten (Hipotesis terbukti).

\section{b. Uji F}

Tabel I4. Hasil Uji F

ANOVA

\begin{tabular}{|c|c|c|c|c|c|c|}
\hline \multicolumn{2}{|c|}{ Model } & $\begin{array}{l}\text { Sum of } \\
\text { Squares }\end{array}$ & df & Mean Square & $\mathrm{F}$ & Sig. \\
\hline \multirow[t]{3}{*}{1} & Regression & 219,894 & 3 & 73,298 & 368,487 &, $000^{a}$ \\
\hline & Residual & 19,096 & 96 & , 199 & & \\
\hline & Total & 238,990 & 99 & & & \\
\hline
\end{tabular}

a.Predictor: (Constant), Motivasi, Lingkungan Kerja, Kepemimpinan.

b. Dependent Variabel : Kinerja

Sumber Data yang diolah: 2021

Hasil uji secara serempak uji $\mathrm{F}$ diketahui besarnya nilai $\mathrm{F}$ sebesar 368,487 dan nilai signifikansi $0,000<0,05$ sehingga dapat disimpulkan secara bersama-sama variabel kepemimpinan, lingkungan kerja dan motivasi berpengaruh terhadap kinerja perangkat desa dikecamatan Wedi, Kabupaten Klaten. 


\section{Koefisien Determinasi $\left(\mathbf{R}^{2}\right)$}

\section{a. Koefisien Determinasi persamaan 1}

Tabel 15. Hasil Koefisien Determinasi

Model Summary

\begin{tabular}{|l|r|r|r|r|}
\hline Model & $\mathrm{R}$ & $\mathrm{R}$ Square & $\begin{array}{c}\text { Adjusted } \\
\mathrm{R} \text { Square }\end{array}$ & $\begin{array}{r}\text { Std. Error of } \\
\text { the Estimate }\end{array}$ \\
\hline 1 &, $698^{\mathrm{a}}$ &, 487 &, 476 & 2,195 \\
\hline
\end{tabular}

a. Predictor: (Constant), Lingkungan Kerja, Kepemimpinan

Sumber Data yang diolah 2021.

Dengan melihat tabel uji determinasi persamaan 1, penetapan determinasi dalam analisis jalur dilakukan dalam melihat besarnya varian yang dilambangkan dengan $\epsilon$, dan besarnya $€ 1$ dihitung dengan Besarnya $\varepsilon_{1}$ dihitung dengan rumus $\varepsilon_{1}=\sqrt{1-R^{2}}$ maka untuk $\varepsilon_{1}$ dengan melihat tabel Uji determinasi persamaan 1, dapat dihitung $: \varepsilon_{1}=\sqrt{1-R^{2}}=\sqrt{ } 1$ $0,487=0,72$ atau 72 .

\section{b. Uji Determinasi (varian) Persamaan 2}

Tabel 16. Uji Determinasi Persamaan 2

Model Summary

\begin{tabular}{|l|r|r|r|r|}
\hline Model & \multicolumn{1}{|c|}{ R } & R Square & $\begin{array}{l}\text { Adjusted } \\
\text { R Square }\end{array}$ & $\begin{array}{r}\text { Std. Error of } \\
\text { the Estimate }\end{array}$ \\
\hline 1 &, $959^{\mathrm{a}}$ &, 920 &, 918 &, 446 \\
\hline
\end{tabular}

a. Predictor: (Constant): Motivasi, Lingkungan Kerja, Kepemimpinan.

b. Dependent Variabel : Kinerja

Sumber: data yang diolah 2021

Dengan melihat tabel uji determinasi persamaan 1, penetapan determinasi dalam analisis jalur dilakukan dalam melihat besarnya varian yang dilambangkan dengan $\epsilon$, dan besarnya $€ 1$ dihitung dengan Besarnya $\varepsilon_{1}$ dihitung dengan rumus $\varepsilon_{1}=\sqrt{1-R^{2}}$ maka untuk $\varepsilon_{1}$ dengan melihat tabel Uji determinasi persamaan 1, dapat dihitung : $\varepsilon_{1}=\sqrt{1-R^{2}}=\sqrt{1-0,920}=0,28$ atau $28 \%$.

\section{c. Nilai Determinasi Total $\left(\mathbf{R}^{2}\right)$}

Berdasarkan nilai $e_{1}$ dan nilai $e_{2}$ maka nilai $R^{2}$ total adalah: $=1-\left(\mathrm{e}_{1}^{2} \mathrm{x} \mathrm{e}_{2}^{2}\right)=1-(0,72 \mathrm{x}$ $0,28)=1-(0,2016)=0,7984$ atau 79,84\%. Ini berarti bahwa kinerja Perangkat Desa di Kecamatan Wedi, Kabupaten Klaten dijelaskan oleh variabel kepemimpinan, lingkungan kerja, motivasi dan kinerja sebesar 79,84\% dan sisanya sebesar $20.16 \%$ dijelaskan variabel lain di luar penelitian ini.

\section{Hasil Korelasi}

Tabel 17. Hasil Korelasi

\begin{tabular}{|rl|r|r|r|r|}
\hline & Kepemimpinan & $\begin{array}{c}\text { Lingkungan } \\
\text { Kerja }\end{array}$ & Motivasi & Kinerja \\
\hline Kepemimpinan & Pearson & 1 &, 886 &, $698^{* *}$ &, $909^{* *}$ \\
& Correlation & &, 100 &, 000 &, 000 \\
& Sig (2-tailed) & 50 & 50 & 50 & 50 \\
$\mathrm{~N}$ & & & & \\
\hline
\end{tabular}


DOI : https://doi.org/10.36778/jesya.v4i2.484

\begin{tabular}{|c|c|c|c|c|c|}
\hline $\begin{array}{l}\text { Lingkungan } \\
\text { Kerja }\end{array}$ & $\begin{array}{l}\text { Pearson } \\
\text { Correlation } \\
\text { Sig (2-tailed) } \\
\mathrm{N}\end{array}$ & $\begin{array}{r}, 886 \\
, 000 \\
, 50\end{array}$ & $\begin{array}{r}1 \\
50\end{array}$ & $\begin{array}{r}, 621 * * \\
, 000 \\
50\end{array}$ & $\begin{array}{r}, 944 * * \\
, 000 \\
50\end{array}$ \\
\hline Motivasi & $\begin{array}{l}\text { Pearson } \\
\text { Correlation } \\
\text { Sig (2-tailed) } \\
\mathrm{N}\end{array}$ & $\begin{array}{r}, 698^{* *} \\
, 000 \\
50\end{array}$ & $\begin{array}{r}, 621 * * \\
, 000 \\
50\end{array}$ & 50 & $\begin{array}{r}, 682 * * \\
, 000 \\
50\end{array}$ \\
\hline Kinerja & $\begin{array}{l}\text { Pearson } \\
\text { Correlation } \\
\text { Sig (2-tailed) } \\
\text { N }\end{array}$ & $\begin{array}{r}, 909 * * \\
, 000 \\
50\end{array}$ & $\begin{array}{r}, 944 * * \\
, 000 \\
50\end{array}$ & $\begin{array}{r}, 682 * * \\
, 000 \\
50\end{array}$ & 1 \\
\hline
\end{tabular}

** Correlation is significant at the 0.01 level (2-tailed)

Sumber: Data yang diolah 2021

Dengan memperhatikan tabel hasil korelasi dapat disimpulkan, hasil korelasional atau hubungan antar variabel penelitian dengan kesimpulan sebagai berikut :

a. Kepemimpinan ke Kinerja adalah 0.909, dapat diartikan bahwa hubungan/korelasi kedua variabel cukup kuat.

b. Kepemimpinan ke Motivasi adalah 0.698, dapat diartikan bahwa hubungan/korelasi kedua variabel kuat

c. Lingkungan Kerja ke Kinerja adalah 0,944, dapat diartikan bahwa hubungan/korelasi kedua variabel sangat kuat

d. Lingkungan Kerja ke Motivasi adalah 0.621, dapat diartikan bahwa hubungan/korelasi kedua variabel cukup kuat

e. Motivasi ke kinerja adalah 0,682 dapat diartikan bahwa hubungan/korelasi kedua variabel kuat.

\section{Pengaruh Langsung dan Pengaruh Tidak Langsung (Total Effect)}

Pengaruh langsung adalah pengaruh dari satu variabel independen ke variabel dependen, tanpa melalui variabel dependen lainnya. Pengaruh tidak langsung adalah situasi dimana variabel independen mempengaruhi variabel dependen melalui variabel lain yang disebut variabel intervening (intermediary). Pengaruh Total adalah jumlah Pengaruh tidak dengan pengaruh langsung. Kesimpulan analisis secara menyeluruh sebagai berikut.

Tabel 18. Hasil Pengaruh Langsung, Pengaruh Tak Langsung dan Pengaruh Total

\begin{tabular}{|c|c|c|c|c|}
\hline $\mathrm{NO}$ & Arah Hubungan & $\begin{array}{l}\text { Pengaruh } \\
\text { Langsung }\end{array}$ & $\begin{array}{l}\text { Pengaruh Tak } \\
\text { Langsung }\end{array}$ & Total Pengaruh \\
\hline $\begin{array}{l}1 . \\
2 . \\
3 .\end{array}$ & $\begin{array}{l}\text { Kepemimpinan } \rightarrow \text { Kinerja } \\
\text { Lingkungan } \rightarrow \text { Kinerja } \\
\text { Motivasi } \rightarrow \text { Kinerja }\end{array}$ & $\begin{array}{l}0,275 \\
0.645 \\
0,090\end{array}$ & $\begin{array}{l}- \\
- \\
-\end{array}$ & $\begin{array}{l}- \\
- \\
-\end{array}$ \\
\hline $\begin{array}{l}4 . \\
5 .\end{array}$ & $\begin{array}{l}\text { Kepemimpinan } \rightarrow \text { Motivasi } \\
\longrightarrow \text { Kinerja } \\
\text { Lingkungan } \rightarrow \text { Motivasi } \\
\text { Kinerja }\end{array}$ & - & $\begin{array}{c}0.687 \times 0,090= \\
0,062 \\
0,012 \times 0,090= \\
0,00108\end{array}$ & $\begin{array}{c}0,275+0,062=0,337 \\
0645+0,00108=0,645\end{array}$ \\
\hline
\end{tabular}

a. Pengaruh Langsung

1) Kepemimpinan terhadap Kinerja $=0,275$

2) Lingkungan Kerja terhadap Kinerja $=0,645$ 
3) Motivasi terhadap Kinerja $=0,090$

b. Pengaruh Tidak Langsung

1) Kepemimpinan melalui motivasi terhadap kinerja $=0,062$

2) Lingkungan Kerja melalui motivasi terhadap kinerja 0,00108

c. Pengaruh Total

1) Pengaruh Kepemimpinan terhadap kinerja melalui motivasi 0,337

2) Pengaruh Lingkungan kerja terhadap kinerja melalui motivasi 0,645

\section{Analisis Jalur}

Secara lengkap hasil diagram jalur dalam penelitian ini dapat dijelaskan penelitian pada gambar Diagram Jalur dibawah ini:

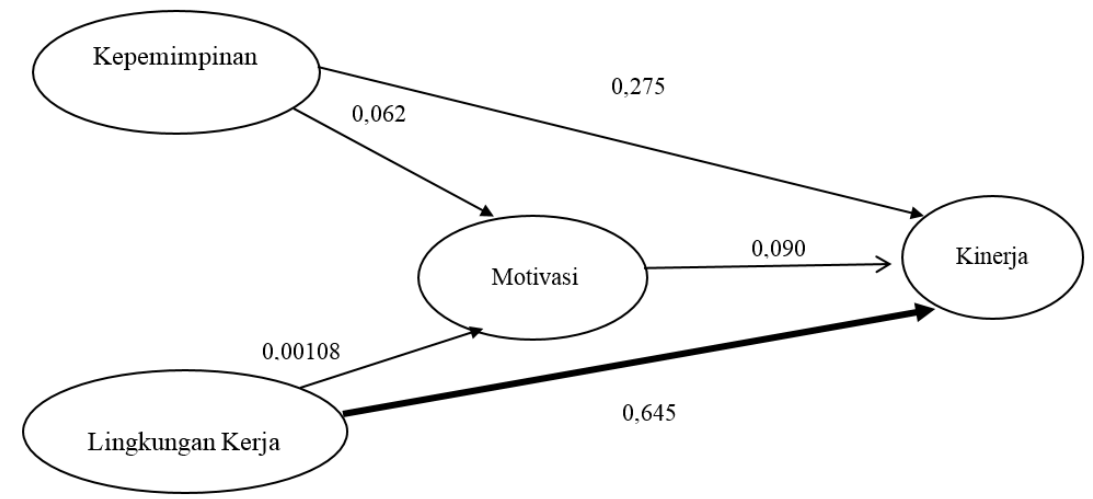

Gambar 1. Hasil Analisis Jalur.

Pengaruh lingkungan kerja terhadap kinerja

Pengaruh langsung lingkungan kerja terhadap kinerja lebih besar dari pengaruh tidak langsung lingkungan kerja terhadap kinerja dengan mediasi dan mempunyai korelasi kuat sehingga untuk meningkatkan kinerja dipilih jalur langsung.

1. Pengaruh kepemimpinan terhadap kinerja

Pengaruh langsung kepemimpinan terhadap kinerja lebih kecil dari pengaruh langsung lingkungan kerja terhadap kinerja.

2. Koefisien determinasi model menghasilkan variasi kinerja dijelaskan oleh variabel kepemimpinan dan lingkungan kerja dengan motivasi kerja sebagai intervening variabel sebesar $79,84 \%$ sisanya $20,16 \%$ dijelaskan variabel di luar model.

\section{KESIMPULAN}

a. Kepemipinan berpengaruh positif dan signifikan terhadap motivasi kerja perangkat desa.

b. Lingkungan kerja berpengaruh positif dan signifikan terhadap motivasi kerja perangkat desa.

c. Kepemimpinan berpengaruh positif dan tidak signifikan terhadap kinerja perangkat desa.

d. Lingkungan kerja berpengaruh positif dan signifikan terhadap kinerja perangkat desa.

e. Motivasi berpengaruh positif dan signifikan terhadap kinerja perangkat desa.

f. Hasil uji F menunjukkan bahwa secara simultan variabel kepemimpinan, lingkungan kerja, motivasi berpengaruh positif dan signifikan terhadap kinerja.

g. Nilai $\mathrm{R}^{2}$ total adalah $79,84 \%$. Ini berarti bahwa kinerja pegawai dijelaskan oleh variabel kepemimpinan, lingkungan kerja, motivasi sebagaai variabel intervening sebsear 79,84\% dan sisanya sebesar20,16\% dijelaskan oleh variabel lain misalnya Perilaku organisasi, Budaya Organisasi, Komunikasi, Diklat, dan lain-lain. 
h. Variabel lingkungan kerja secara langsung efektif meningkatkan kinerja pegawai, karena mempunyai pengaruh yang paling besar.

\section{SARAN}

Peneliti memberi beberapa saran yang dapat dijadikan pedoman untuk meningkatkan kinerja perangkat desa antara lain:

a. Lingkungan kerja perlu untuk ditingkatkan kembali guna mendukung pelayanan publik kepada masyarakat yang membutuhkan.

b. Motivasi perangkat desa dilakukan dengan cara memberikan kesempatan kepada para perangkat desa untuk mencapai keberhasilan dalam meningkatkan layanan kepada masyarakat , memberikan kesempatan kepada perangkat desa untuk dapat mengekspresikan kreativitas kerja dalam melaksanakan pekerjaan demi meningkatkan suasana kerja yang menyenangkan.

\section{DAFTAR PUSTAKA}

Andari. 2016. Pengaruh Kepemimpinan dan Lingkungan Kerja terhadap Kinerja Pegawai Dinas Koperasi dan UMKM Provinsi Banten. Jurnal Sains Manajemen Vol 2(2): 16-26.

Azwar, Saifuddin. 2010. Metode Penelitian. Yogyakarta. Pustaka Pelajar.

Eka, S.N., Ismiyati. 2015. Pengaruh Kepemimpinan, Fasilitas Kerja, dan Motivasi Kerja terhadap Kinerja Perangkat Desa di Kecamatan Mandiraja, Kabupaten Banjarnegara. Economic Education Analysis Journal Vol 4(2):562-574.

Ghozali, Imam. 2011. Aplikasi Analisis Multivariete dengan SPSS Cetakan ke 4. Badan Penerbit Universitas Diponegoro. Semarang.

Gibson, J.L., J.M. Ivancevich, dan J.H. Donnelly Jr. 2000. Organization: Behaviour, Structure and Process. McGraw-Hill Companies Inc. Boston.

Hardiyana, A dan F. Helwiyan. 2011. Pengaruh Kepemimpinan, Motivasi, dan Lingkungan Kerja terhadap Kinerja Pegawai Badan Kepegawaian Pendidikan dan Pelatihan Kabupaten Bandung. Jurnal Ekonomi, Bisnis, dan Enterpreneurship Vol 5(2):86-96.

Hasibuan, Malayu. 2011. Manajemen Sumber Daya Manusia. Jakarta. PT. Bumi Aksara.

Mangkunegoro, AA. Anwar Prabu. 2010. Manajemen Sumber Daya Manusia. Bandung. PT. Remaja Rosdakarya.

Marnis Atmojo. 2012. The Influence of Transformasional Leadership on Job Satisfaction. Riau.

Mulyono. 2012. Manajemen Sumber Daya Manusia. Jakarta. CV. H. Mas Agung.

Pramanitia H. 2014. Hubungan antara Motivasi, Kompetensi, dan Kepemimpinan Demokratis dengan Kinerja Pegawai Pemerintahan Desa (Studi Kasus: 15 Desa di Kecamatan X Kabupaten Bogor). e-Journal Graduate Unpar Vol 1(1): 38-44.

Prawirosentono, S. 2010. Kebijakan Kinerja Karyawan. Yogyakarta. BPFE.

Sartono, A. 2011. Manajemen Keuangan (Teori dan Aplikasi). Edisi Keempat. Cetakan Ketujuh. Yogyakarta. BPFE.

Sedarmayanti. 2011. Manajemen Sumber Daya Manusia. Jakarta. Revika Aditama Eresco. 
Siagian, Sondang P. 2012. Sumber Daya Manusia. Jakarta. Bumi Aksara.

Sugiyono. 2012. Metode Penelitian Bisnis. Bandung. CV Alfabeta.

Timpe, D.A. 2011. Seri Manajemen Sumber Daya Manusia (Kinerja/Performance) Cetakan ke 4. Jakarta. PT. Elex Media Komputindo.

Susetyo, A. 2013. Pengaruh Gaya Kepemimpinan, Lingkungan Kerja, terhadap Kinerja Perangkat Desa di Kecamatan Kebumen dengan Kepuasan Kerja sebagai Variabel Intervening. Jurnal Fokus Bisnis Vol 12(1): 17-37.

Widarjono, A. 2010. Analisis Statistika Multivariat Terapan Edisi Pertama. Yogyakarta. UPP STIM YKPN

Yukl, Gary. 2010. Kepemimpinan dalam Organisasi Edisi ke 5. Jakarta. PT. Indeks. 